\title{
"My Cleverness, I Assure You, Has Grown INFERNAL": Playing STUPID WITH HENRY JAMES
}

\author{
Bruno Penteado ${ }^{1}$
}

Well, since she wasn't stupid she was intelligent; it was he who was stupid - the proof of which was that he would do what she liked. (Henry James, “The Wings of the Dove”)

Those who "succeed" do so only in the most problematic ways, often by accepting the patriarchal terms of their societies and learning to "play the game". (John Carlos Rowe, The Other Henry James)

\begin{abstract}
This article reads Henry James's bias against his native America ironically. I offer a two-fold reading of the staging and performance of stupidity: it is both a strategy of resistance and a rhetoric of disavowal of responsibility. I contend that Henry James offers Milly Theale, the American rotagonist of "The Wings of the Dove", the possibility of playing up to European assumptions about the New World through a performance of stupidity. I also argue that feigning ignorance is also renouncing responsibility, as exemplified in Merton Densher's conduct. James abstains from conclusions, allowing stupidity to rule in the end.
\end{abstract}

Keywords: Henry James; Ethics; Ideology Critique.

In A Light Man, an early text by Henry James that appeared in The Galaxy in July 1869, Maximus Austin, upon his return from Europe to New York, announces in the opening paragraph:

1 Adjunct Lecturer, Departament of English, Indiana University Souft Bend, Estados Unidos: bruno_penteado@alumni.brown.edu. 
“My Cleverness, I Assure You, Has Grown Infernal”: ...- 306

I have changed my sky without changing my mind. I resume these old notes in a new world. I hardly know of what use they are; but it's easier to preserve the habit than to break it. I have been at home now a week - at home, forsooth! And yet after all, it is home. I'm dejected, I'm bored, I'm blue. How can a man be more at home than that? Nevertheless, I'm the citizen of a great country, and for that matter, of a great city. I walked today some ten miles or so along Broadway, and on the whole I don't blush for my native land. We're a capable race and a good-looking withal; and I don't see why we shouldn't prosper as well as another. (JAMES, 1999, p. 399)

The first change of sky - from America to Europe - arguably incurred a change of mind, rather a refusal of the American mind. The return to America, the second change of sky, keeps the mind the way it became in the Old World: cultured, historicized, and aestheticized. Is it boredom that leads to the obscene display of pride for one's native (here relating to nature) land? One cannot assume that political independence immediately accompanies a drive for cultural autonomy. But if it comes to be, one is nevertheless facing a cultureless culture, a culture of ahistoricity, a big, thick layer of blankness forever doomed to yield nothing. American culture is, after all, a scandalous bastard. Or so received ideas, nineteenthcentury Doxa, would have one believe.

This move, and it is, quite literally, a move - from America to Europe - is, as any reader of James knows well, present in almost all of his works. From Roderick Hudson to Lambert Strether, from Christopher Newman to Milly Theale, from Isabel Archer to Maggie Verver, Americans cross the Atlantic to fulfill or answer a call (more often than not, the call is artistic), to try to fix some nefarious situation caused by Europe's corruption of Americans, to exercise freedom, to find happiness, that "swift carriage, of a dark night, rattling with four horses over roads that one can't see" (JAMES, 1995, p. 146), as Isabel Archer beautifully lets us know. More importantly, Americans in James are almost always enveloped in an aura of simplicity, even stupidity, but one must wonder to what extent such simplicity and stupidity are attributes Europeans have, throughout history and through tradition, imputed to Americans.

In 1878 James published a short essay called "Americans Abroad", a piece that touches upon the conspicuous outsideness of Americans in Europe as it considers them from a skeptical perspective: how are they seen by Europeans? James sees the complexities of European ideologies about Americans in states that shift from alacrity to self-consciousness. Europeans, he writes, during the months of great American influx into the continent, "have encountered, for instance, a few more specimens of the 
unattached young American lady - the young lady travelling for culture, or relaxation, or economy - and, according to their different points of view, she has seemed to them a touching or a startling phenomenon" (JAMES, 1993, p. 787). Not unlike Daisy Miller, Isabel Archer, Milly Theale, and Maggie Verver, for instance. What betrays Americans, however, is their inherent, insurmountable outsideness; to add insult to injury, whenever Americans try to circumvent it, it becomes even more conspicuous. These are times when America is "out of the European circle politically and geographically" (JAMES, 1993, p. 787), which is one of the reasons that Europeans are so ignorant of America. The nation is far too peculiar to be grasped by the European mind:

We are the only great people of the civilized world that is a pure democracy, and we are the only great people that is exclusively commercial [...] Add the remoteness represented by these facts to our great and painful geographical remoteness, and it will be easy to see why to be known in Europe as an American is to enjoy an imperfect reciprocity. (JAMES, 1993, pp. 787-788)

To make matters more complicated, the following year James's essay on Nathaniel Hawthorne was published, an essay that contains the following paragraph listing everything that America lacks:

\begin{abstract}
No State, in the European sense of the word, and indeed barely a specific national name. No sovereign, no court, no personal loyalty, no aristocracy, no church, no clergy, no army, no diplomatic service, no country gentlemen, no palaces, nor manors, nor old country houses, nor parsonages, nor abbeys, nor little Norman churches; no great Universities nor public schools - no Oxford, no Eton, nor Harrow; no literature, no novels, no museums, no pictures, no political society, no sporting class - no Epsom nor Ascot! (JAMES, 1984, pp. $351-352)^{2}$
\end{abstract}

2 Writing about the reception of James's essay, McCall (1997, pp. 112) elicits how it touched a nerve in the New World: "When Hawthorne first appeared in December of 1879, there was considerable public outcry against James's severe tone and general condescension. Who was this traitor of his native land, this expatriate snob who had 'gone British' and thumbed his London nose at his predecessor's achievement? In January of the new year James wrote to William Dean Howells that the American critics were 'bloodhounds' ferociously drenching 'the decent public' with his 'gore'. In an anonymous review in The Atlantic the following month Howells said that 'in some quarters' James would be found guilty of 'high treason'. Harper's hoped that the book had been written only in a 'momentary fit of indigestion'. James called these reviews 'a melancholy revelation of angry vanity, vulgarity, and ignorance”'. 
James's so-called "international theme" 3 in a way speaks of a crisis in Europe's geopolitical power and arguably reflects both an increasing fear and suspicion of America's monstrously-growing capitalism and the collapse of traditional (European) forms of social stratification in this society in which power is increasingly displaced from tradition to money. ${ }^{4}$ Simplifying Americans and attributing to them an inherent disadvantage by way of discourses that range from America's ahistoricity to the infamous degeneracy argument are ideological positions with which James constantly struggled. This somewhat biased international theme plays an important role in his 1902 novel "The Wings of the Dove", my main corpus in this article. More importantly, this bias is consistently associated with stupidity in the novel, insofar as Milly Theale, the moribund American heiress, is perceived as stupid, simple-minded, and gullible, mainly because of the ideologies that sustain Europeans' conception of the attributes of the American girl.

Milly's playful strategy, I argue, relies on her understanding of the ideologies that pre-inform others of her given her American national origin. As we will see, Milly's unrepresentability, a topic on which critics have long been insisting, dictates that she be represented indirectly, that is, through the thinking of other characters, ${ }^{5}$ who in their turn make use of received ideas about America(ns) in the constitution of their experience of Milly. Fowler (1984, p. 85), studying James's “American girl”, suggests that Milly Theale's illness "might be viewed as a symbol or metaphor for

3 In one of the most interesting accounts of James's international theme, Roberts (2012) notices a shift in James's perception of America's position vis-à-vis Europe's geopolitical centrality in the second half of the nineteenth century. Roberts points out that in the later fiction the international theme seems to shift from predatory Europeans exploiting the innocence of Americans to extremely clever Americans able to ward off European corruption. James, Roberts (2012, p. 110) essays, “[...] possessed an extremely sensitive seismometer alerting him to subterranean shifts in the tectonic plates underlying the conduct of international relations in the late nineteenth and early twentieth centuries, especially the changing balance of power between the United States and Europe". As my reading of Milly's perceived stupidity will show, I agree with Roberts's claim that "James is often interpreted, somewhat simplistically, as a writer who juxtaposed innocent and vulnerable Americans with scheming, predatory Europeans, who come out victorious in material terms, leaving the Americans with the moral triumph" (p. 92).

4 See Gilje (2006, pp. 30-31): "Americans did not invent banking, they democratized it. Initially banks even in the United States were elitist institutions. [...] But privilege in the increasingly egalitarian United States was difficult to maintain".

5 Apropos of thinking and the externalization of consciousness in "The Wings of the Dove", see Cameron (1991, pp. 122-168). 
an inner deficiency created by her situation as an American woman." Part of the novel's structure, Fowler argues, is concerned not with Milly's physical well-being, but with "the spiritual deficiency that unfits [her] for life"; her illness "is rooted in some way in her cultural identity" (FOWLER, 1984, p. 85). She concludes: "[I]t is not simply Milly Theale's physical malady that makes her a ready victim of Lancaster Gate and its milieu; more importantly, her own character and personality, of which her illness is both a result and a symbol, prevent her from coming to terms with life" (p. 85). To Fowler's argument I add that her "cultural identity" is perceived by her European friends as synonymous with stupidity, and that this stupidity, of which Milly is fully aware, opens up the path for a structure of play throughout the novel, mainly playing stupid. As a matter of fact, these ideologies concerning America are the raw materials of which Milly makes use in her performance of stupidity. Indeed, her Americanness is partly responsible for the scheming to which she is subjected by Kate and Densher; however, I see it not as an essentialist trait that determines the alleged stupidity that ensues, but as a performative element she masters and which she plays up as a form of resistance, even resilience.

Brooks (1995) argues that "The Wings of the Dove" plays out as a melodrama, and that Milly's death is staged as spectacle of renunciation and sacrifice. My reading envisages Milly's spectacle as interactive: she will respond to the views of her Americanness the characters of English society she comes across hold, views that almost always attribute stupidity to her, by playing these attributes out. I therefore suggest that her staging of stupidity becomes one of the many spectacles the novel puts on, as characters and readers struggle to read her, all of them (and us) caught in a generalized state of bewilderment and stupor. If playing stupid, for Deleuze, is a line of flight, ${ }^{6}$ the stupidity with which the novel is concerned will be the dove's flight route as she learns, through the corruption to which she will be subjected (perhaps even to which she will subject herself), what it means, as James tells us in the preface to the novel, to have a "sense of having lived" (JAMES, 2006, p. 197).

6 See Mengue (2013, p. 9): "La politique deleuzienne a pour objectif la libération des possibilités de vie qui restent emprisonnées par une organisation sociale déterminée. Et pour échapper aux puissances de contrôle et de répression, Deleuze, selon nous, dirait qu'il conviendrait de faire l'idiot". 
"The Wings of the Dove" is perhaps James's greatest novel of play. After all, as Lionel Croy tells his daughter Kate in the novel's opening scene, "the only way to play the game is to play it" (JAMES, 2006, p. 228).7 And in this novel that challenges the limits of representation, Kate's plan, like a puzzle, comes to us in terribly shattered and enigmatic bits and pieces. During a dinner party hosted by Aunt Maud, Kate sets the trap for Milly:

"She has really been a perfect success [...] and she has taken it like a perfect angel. If you can imagine an angel with a thumping bank-account you'll have the simplest expression of the kind of thing. Her fortune's absolutely huge. [...] It is open to her to make, you see, the very greatest marriage. I assure you we're not vulgar about her. Her possibilities are quite plain."

Densher showed he neither disbelieved nor grudged them. "But what good then on earth can I do her?"

Well, she had it ready. "You can console her."

"And for what?"

"For all that, if she's stricken, she must see swept away. I shouldn't care for her if she hadn't so much", Kate very simply said. And then as it made him laugh not quite happily: "I shouldn't trouble about her if there were one thing she did have." The girl spoke indeed with a noble compassion. "She has nothing."

\section{$[\ldots]$}

"I want", said [Kate], "to make things pleasant for her. I use, for the purpose, what I have. You're what I have of most precious, and you're therefore what I use most".

He looked at her long. "I wish I could use you a little more." After which, as she continued to smile at him, "Is it a bad case of lungs?", he asked.

Kate showed for a little as if she wished it might be. "Not lungs, I think. Isn't consumption, taken in time, now curable?"

"People are, no doubt, patched up." But he wondered. "Do you mean she has something that's past patching?" (pp. 451-452)

7 All quotations from “The Wings of the Dove” are from this edition. 
If Densher wants to use Kate a little more, he will first have to use Milly. Milly's "possibilities are quite plain”, which comes to no surprise to us, for she is being treated by Kate as a stupid creature (Kate speaks with a "noble compassion") whose only plain possibility, given her wealth, is to get married, thus transferring it to the man who is able to capture her in her flight towards death. The center of European attentions, a lovable, convenient, and pleasing creature, the American girl must think her wings have not been clipped by the scissors of death, that the freedom she seeks in Europe can materialize itself in or as a man, a man who, as Sir Luke Strett purports, would also be an antidote. For as long as she is single, "she has nothing", that is, no use for Kate whatsoever. If she's past patching, thenothingness of her role as a wealthy, single American woman must be brought to something. "If she is stricken", all she must see swept away, apart from her own life, is her fortune, and whose hands would be better suited to take it obsequiously than Kate's? Therefore Kate will use Densher's hands, her most precious asset.

Kate proceeds when pushed by Densher, who is struggling to figure out what his role in the play is: "I believe that if she's ill at all she's very ill. I believe that if she's bad she's not a little bad. I can't tell you why, but that's how I see her. She'll really live or she'll really not. She'll have it all or she'll miss it all. Now I don't think she'll have it all" (p. 452). Kate, from the nothingness Milly is to her at present, will have it all herself. And "one can't begin too soon" (p. 453). Why would Kate wait, if she has a "duty" (this word abounds in the first two scenes of the novel, when Kate visits her father and then her sister) to her family, if, in their nothingness, she is everything they have? Densher, Kate reasons, must be as much of a pawn as Milly, considering that she, Kate Croy, is a pawn vis-à-vis her family: "Don't guess. Only do as I tell you" (p. 454). This resonates with what Lionel Croy, whose "dishonor" is a "part of" Kate, and later her sister tell her when they remind her of her "duty": she must do as they say, lest she should live with the guilty conscience of having abandoned her poor old man (who tells her that, should she do it, that is, abandon him, he would make her regret it) and her widowed sister (who has four mouths to feed). Milly's ineptitude and vulnerability, the vulnerability of the gullible, her lack of judgment concerning European life, its rules, and the way the game is played across the Atlantic become a topic of conversation: "Milly, it's true, [...] has no natural sense of social values, doesn't in the least understand our differences or know who's who or what's what" (pp. 
456-457). She is clueless, especially because she will fall prey to Kate's plan: "She doesn't resemble me, [...] who at least know what I lose" (p. 457). Milly has so much that she cannot even know what it is she would lose; the novel provides Mrs. Stringham's impression of Milly's inexistent difficulties in Book 3: she has "a sense closed to the general question of 'difficulty', which she got rid of furthermore not in the least as one had seen many charming persons do, by merely passing it on to others. She kept it completely at a distance: it never entered her circle" (p. 296).

But as a bewildered Densher tries to play along, he utters to Kate that "all women but you are stupid. How can I look at another? You're different and different - and then you're different again". ${ }^{8}$ All women but Kate are stupid, or so Densher thinks. Like the Prince submitting to Charlotte in The Golden Bowl, Densher will passively submit to Kate's cunningness. If all women are stupid, Milly is stupid. So as he passively agrees to "be nice to her", now that Kate has told her that Densher and herself are not engaged, he must be led along the way - or so he prefers to believe:

He had had his brief stupidity, but now he understood. [Aunt Maud] had guaranteed to Milly Theale through Mrs. Stringham that Kate didn't care for him. She had affirmed through the same source that the attachment was only his. He made it out, he made it out, and he could see what she meant by its starting him. She had described Kate as merely compassionate, so that Milly might be compassionate too. "Proper" indeed it was, her lie - the very properest possible and the most deeply, richly diplomatic. So Milly was successfully deceived. (p. 463)

Overcoming his own stupidity, he sees it: Milly will be duped, and why shouldn't she, if she is, after all, a stupid woman (which, for Densher, is a pleonastic construction), a dying, scandalously wealthy woman? Attributions of stupidity to Milly, regardless of their originating in ideologies about her Americanness or their being misogynistic violence done by androcentric minds, would apparently thus justify her Christ-like sacrifice, her status as the sacrificial victim she seeks to be - in order to "achieve, however briefly and brokenly, the sense of having lived" (p. 197). Her perceived simplicity is also a byproduct of the ideologies that

8 See Yeazell (1976, p. 55): "Densher will prefer to keep many of his mental cupboards locked, passively allowing Kate to assume charge of the keys. And she will respond by doling him out his lumps of sugar - offering him, bit by bit, only palatable interpretations of their acts, interpretations which he can pleasantly swallow, and hold back anything which might strike his moral palate as bitter". 
surround and constitute what a European would call "the American girl":9 Densher visits Milly following his conversation with Kate, but finds it very hard to play her along. His memories of his time with her in America are enmeshed in his need to move forward with Kate's plan and his assessment of Milly's righteous claim to victimhood: "He had talked with Kate of this young woman's being 'sacrificed', and that would have been one way, so far as he was concerned, to sacrifice her. Such, however, had not been the tune to which his at first bewildered view had, since the night before, cleared itself up" (pp. 464-465). James is careful to distinguish their previous, legitimate American relation, "proper and harmless" (p. 464), from their current, bewildering European one. For Densher, "the princess, the angel, the star, were muffled over, ever so lightly and brightly, with the little American girl who had been kind to him in New York and to whom certainly - though without making too much of it for either of them - he was perfectly willing to be kind in return" (p. 535). The American girl, Fowler $(1984$, p. 8$)$ writes, is a paradox in James:

\begin{abstract}
though [the American girl,] in her innocence, spontaneity, and purity [...] offers an alternative to the old corruption of Europe and the rampant materialism of America, yet because she has "been grown in an air in which a hundred of the 'European' complications and dangers didn't exist", she often proves, as James expresses it in "The Wings of the Dove", unable to take "the whole assault of life". She thus symbolizes for James, as Nina Auerbach has observed, "simply and ambiguously, America itself".
\end{abstract}

As Milly practices her routine, she must be careful about what she says, for Europeans' impressions of her will greatly be informed, before they are constituted into experience, by the ideologies bestowed on Americans: Lord Mark, learning that she is American, reasons that "she was already [...] thinking what she should say on her other side - which was what Americans were always doing” (p. 315). James, however, jabs his finger into America's open wound: "She needn't in conscience say anything at all; but Americans never knew that, nor even, poor creatures, yes (she had interposed the 'poor creatures!') what not to do" (p. 315). Americans are gregariously clueless: if they never know what not to do, they are constantly, one expects, putting their foot in their mouth. ${ }^{10}$ The

9 James's cousin Mary Temple, who inspired both Milly Theale and Isabel Archer and died in 1870 , is described by him in Notes of a Son and a Brother as the quintessential American girl. I thank Paul Armstrong for pointing this out to me. 1o For James and bad social manners, see Puckett (2008). 
narrator, gearing into free indirect speech, insists that the interjection "poor creatures", which condescendingly decries Americans, is uttered by Milly; let there be no doubt that Milly is playing along with the ideologies about her "race":

The burdens they took on - the things, positively, they made an affair of! This easy and after all friendly jibe at her race was really for her, on her new friend's part, the note of personal recognition so far as she required it; and she gave him a prompt and conscious example of morbid anxiety by insisting that her desire to be, herself, "lovely" all round was justly founded on the lovely way Mrs. Lowder had met her. He was directly interested in that, and it was not till afterwards she fully knew how much more information about their friend he had taken than given. Here again for instance was a characteristic note: she had, on the spot, with her first plunge into the obscure depths of a society constituted from far back, encountered the interesting phenomenon of complicated, of possibly sinister motive. (pp. 315-316)

When she "turns her face to the wall" (p. 599), she turns her back to the "society constituted from far back", in which she cannot take part, given her provinciality. Her "desire to be "lovely", itself determined by a previous impression she made on Mrs. Lowder, is yet another "burden" that the American girl takes on. The late James, who is also always already the James of the international theme, is concerned with "the reconstruction of America, in terms of a Europe seen by way of America" (RIGHTER, 2004, p. 5). The reconstruction of America, of which Milly's construction through her associates' consciousnesses is a synecdoche, is preceded by a reconstructed Europe, reconstructed, that is, through previous constructions of America. Milly is read according to ideologies about America, and she is constructed by European consciousnesses that are already ideologically informed of what the American girl is, or rather should be like.

However, later in the novel, when Lord Mark pays too much attention to Milly, she realizes that she has made him feel "uncertain" of his "certainties" (p. 324), and this because of herself, "the handsome girl" (p. 311). What are the "certainties" of which he is made "uncertain"? Milly reasons that he was uncertain "of his certainties about a mere little American, a cheap exotic, imported almost wholesale and whose habitat, with its conditions of climate, growth and cultivation, its immense profusion but its few varieties and thin development, he was perfectly satisfied" (p. 324). Since, we can be sure, Lord Mark never uttered these words, what we have here is Milly staring into ideology's eyes, recognizing 
the discourses around "her race" that float around her, determining the impressions that others will harvest in the making of their experience of her. These discourses do not only interpellate, in an Althusser-like manner, others in their making of their experience of Milly; they also interpellate Milly, who takes the call and shines on stage: "it was as if there might have been a question of her falsifying for the sake of her own show" (p. 324), Lord Mark ponders." Milly is at times stupefied by ideology: "it was so little her fault, this oddity of what had 'gone round' about her, that to accept it without question might be as good a way as another of feeling life" (p. 358, emphasis mine). One might as well play along; mulling it over, accepting "it without question", is one form of playing stupid that can be envisaged as a strategy:

\footnotetext{
"And, as I told you before, I'm American. Not that I mean that makes me worse. However, you'll probably know what it makes me."
}

"Yes" - he even showed amusement for it. "I know perfectly what it makes you. It makes you, to begin with, a capital case.”

She sighed, though gratefully, as if before the social scene. "Ah there you are!". (p. 374)

There we are too. J. Hillis Miller (2005, p. 193) proposes that, in "The Wings of the Dove", "there you are" and its hybrids name "the triumphant moment when one character has scored a point against another in the ceaseless battle for domination." Hillis Miller proceeds: "it names a kind of irreducible being there, an embeddedness in a situation that is both a life situation, that is, a social and familial situation in relation to others, and a material situation" (p. 196). There they are, hailed by ideology; Milly herself names the ideology, spotting it, addressing it: there you are, I am "a mere little American, a cheap exotic, imported almost wholesale", I come from a "habitat" that has particular and distinct "conditions of climate, growth and cultivation".

Sir Luke Street, Milly's doctor, is also entangled in ideology's tentacles: "He in fact confessed to it, in his way, as to an interest in her combinations, her funny race, her funny losses, her funny gains, her funny freedom, and, no doubt, above all, her funny manners - funny, like those of Americans at their best, without being vulgar, legitimating amiability and helping to

11 See Brooks (1995, p. 179): "Milly's will to live is itself an analogue of the melodramatist's desire to intensify experience, to make 'life' a heightened drama”. 
pass it off" (p. 382). Milly, that "dear American thing" (p. 392), with her "American mind" (p. 399), references the entirety of the American "race", this funny "race" one can easily spot: at the National Gallery, "one would sit in public and count the Americans" (p. 408). Milly's performance of her Americanness, as I have been arguing, can get her far, especially at troubling moments. When she comes across Kate and Densher, who in his turn has just returned from America, at the National Gallery (let us recall that Milly fails to mention to Kate that they, Densher and herself, are acquainted), in a scene that reminds us of Strether's sight of Chad and Madame de Vionnet in a boat in France in The Ambassadors, she is given her cue:

The finest part of Milly's own inspiration [...] was the quick perception that what would be of most service was, so to speak, her own native wood-note. She had long been conscious with shame for her thin blood, or at least for her poor economy, of her unused margin as an American girl - closely indeed as in English air the text might appear to cover the page. She still had reserves of spontaneity, if not of comicality; so that all this cash in hand could now find employment. She became as spontaneous as possible and as American as it might conveniently appeal to Mr. Densher, after his travels, to find her. She said things in the air, and yet flattered herself that she struck him as saying them not in the tone of agitation but in the tone of New York. In the tone of New York agitation was beautifully discounted, and she had now a sufficient view of how much it might accordingly help her. (pp. 311-312)

So, if at a certain moment in the text, Kate tells Densher that "my cleverness, I assure you, has grown infernal” (p. 424), stupidity's love of inversion would stupidly state that Milly's stupidity, I assure you, has grown heavenly. The text gives us two options, which are not exclusive: she can be stupid by accepting the stupidity imputed to her on the grounds of her "native wood-note", or she can make better use of her "margin as an American girl". If Americans are on the margins, this marginality gives them margin for play: in the English air, Milly's Americanness is all that is seen. Kept safe in the bank of stupidity, her spontaneity and comicality must now be withdrawn. This is her cash in hand: she buys (into) the ideologies being offered to her, thus accumulating raw materials for the props she will use in her performance.

If we think Milly's gift to Densher as Derrida (1991) thinks the gift, her final act is one of selfishness. If the gift (not the authentic one, however), for Derrida, carries in itself indebtedness, Densher cannot be indebted to 
Milly, nor can he refuse the gift; she is "dead, dead, dead" (p. 359). Her gift carries with itself its very acceptance, for Densher cannot refuse it, nor does he have access to the very announcement of the gift's being given, the verbalization of the gift, for a) he saves Milly's letter for Kate to open; and $b$ ) the letter is eventually burned without being read. By giving the gift that cannot not be accepted, Milly enacts her ultimate stupidity of kindness and generosity, a gesture than can, that must also be interpreted as an act of revenge. If giving implies an imposition to seeing the gift as an act of kindness and generosity, her gift becomes an injunction to the thought of her, simply because the gift is an exchange that, thought to originate in kindness and generosity, imposes the necessity of seeing it exactly as an act of kindness and generosity.

Learning to live and bestowing death upon herself as she bestows her death upon others - this is her gift to herself, one could argue, a gift that is reified in what she bequeaths, at the end of the novel, to Densher. Derrida's formula "apprendre à vivre enfin", extracted from Spectres de Marx and retaken in Apprendre à vivre enfin, an interview with Jean Birnbaum, is the link one needs to bring together life and death with regard to the question of the gift and the ensuing responsibility for it. Derrida writes that the formula "hésite [...] entre l'adresse comme expérience (apprendre à vivre, n'est-ce pas l'expérience même?), l'adresse comme éducation et l'adresse comme dressage" (DERRIDA, 1993, p. 14). More importantly, learning to live from and by oneself, "s'apprendre soi-même à vivre", is, "pour un vivant, l'impossible", for one does not learn to live by and from oneself, "seulement de l'autre et par la mort" (DERRIDA, 1993, p. 14). Learning to live, "c'est mûrir" (which is one letter short of mourir), "éduquer aussi” (DERRIDA, 2005, p. 23). Echoing Heidegger's Sein-zum-Tode, he proceeds: "Apprendre à vivre, cela devrait signifier apprendre à mourir [...]" (DERRIDA, 2005, p. 24).

In Donner la mort, Derrida (1999, p. 62) advances some of these propositions in what he calls "l'appréhension de la mort", that is,

le souci, la sollicitude inquiète, le soin pris de l'âme (epimeleia tes psukhes) dans la melete thanatou que la signification apportée à la mort par une attitude interprétative qui dans des cultures différentes, à des moments distincts, par exemple dans le mystère orgiaque, puis dans l'anabase platonicienne, puis dans le mysterium tremendum, appréhende autrement la mort, s'en donnant chaque fois une approche différente. [...] Chaque fois le moi anticipe sa mort en lui donnant ou en lui conférant une autre valeur, se donnant, se ré-appropriant en vérité ce qu'il ne peut simplement s'approprier. 
After Milly's death, when Kate and Densher are conferring, he, in possession of Milly's letter addressed to him, which remains unopened, transfers the responsibility for their deeds to Kate. This is his gift: "If I had broken the seal - exactly - I should know what's within. It's for you to break the seal that I bring it" (p. 675). Kate, however, sees no need to break the seal: the very fact that Milly addressed a letter to Densher is "the proof" (p. 675) of her love, and consequently of her gift. The letter, Densher reasons, "has been timed" (p. 675), deliberately coming to his possession on Christmas Eve. Christmas, Kates adds with "a strange smile", is "the season of gifts!" (p. 675). Kate informs him that there is no need to open it: "I trust her" (p. 676). But Densher wants to make his gift: "You played fair with me, Kate; and that's why - since we talk of proofs - I want to give you one. I've wanted to let you see - and in preference even to myself - something I feel as sacred" (p. 676). His gift to her, the sacred letter, for it was written by the sacrificial victim, the letter in which Milly the Martyr informs him, one assumes, of her gift (of death), is one of reciprocity, a gift that repays Kate for her "splendid act of generosity" (p. 676) in Venice, that is, the gift of her body to him. Densher refers to her consent to sex, which in itself was a product of blackmail, as a "tribute" and a "sacrifice" (p. 676). Her gift to him, then, was as sacrificial as Milly's. And as she takes the letter, for Densher "absolutely desires [her] to take it", she utters "trust me" and, holding the gift, adds: "To hold it is to know" (p. 677). And then she throws it in the fire.

Milly's timed sacrifice, the gift of her death that in its turn engenders the gift of money, is tantamount to the gift of Christ's death which absolves the whole of humanity. ${ }^{12}$ If, in Christianity, the gift of Christ's death is given freely to all (the gift of redemption depends, of course, on free will, the free will whether to accept Christ's gift), an individual's responsibility is to take it, lest Christ's death should be in vain. Kate plans to accept Milly's gift, but, contrary to what one thinks if one sees Densher's position as ethical, she is not unwilling to take responsibility for it. Her burning the letter betrays her trust in Milly's "selfless kindness", that is, her stupidity,

\footnotetext{
12 See Miller (2005, p. 207): “Kate's naming of Milly a dove [...] is the eponymous act of the novel. It gives the novel its name. The title names not just Milly's malign, death-dealing beneficence but also the novel itself as repeating that. [...] Like other victimized women in James's novels, [...] Milly uses her beneficence to bring devastation to the world she enters, here by ultimately separating Kate and Densher forever". However, as I have been arguing, this separation can only be said to take place because of Densher's refusal of responsibility for the gift.
} 
here embodied not in the letter, but in its having been addressed. If she was despicable to Milly, it was because she was ethically bound to her family (their "well-being", they insist on reminding her, is her "duty"). Textually, the gift of the letter cannot be accepted, nor can the letter itself be read, because in it may lie the proof of Milly's very own selfishness, for she knows that her gift of death, and the gift of money that results from it, will only allow for Kate's and Densher's salvation if they take the burden of responsibility that must come with the gift. Kate, I believe, is ready to take it, to take them, to be precise, both the gift and its ensuing responsibility. My hermeneutical grid therefore invalidates Densher's decision not to take the money as an ethical imperative, a decision he makes to preserve his shattered dignity as Milly's haunting memory hovers over his head. I see it as a rather unethical move, his refusing responsibility for his deeds, refusing to partake in Milly's death, refusing, at last, to see his own doing in the world, to take responsibility for the imprints he has left around himself and others. Densher does not think that his "tacit lies" (the syntagm is Hillis Miller's) played a part in Milly's crisis: as a matter of fact, Densher blames it on Lord Mark when he mentions to Mrs. Stringham that "he doesn't know what he's done to her", and that he is "an idiot of idiots" who is at once "awfully clever" (p. 609).

Milly's gift is nevertheless caught in a network that disavows her alleged kindness, for it selfishly victimizes her, turning her death into a sacrifice. For Milly to be a victim, the responsibility for her death (no wonder her illness is unnamed) must lie elsewhere, it must be enmeshed in the very gift that engenders the responsibility that must be taken. The validation of her victimization can only be achieved through the validation of her associates' plans; what other way to legitimize her sacrifice but by letting their envisaged plot against her unfold? In her fear and trembling (her mysterium tremendum), which gives her the wings of a dove in order to be able to fly away and perform her final anabasis, act out her final, melodramatic role, ${ }^{13}$ her frail body becomes a space of haunting, where the specters of her wealth that are to haunt and determine Densher's and Kate's taking of responsibility show themselves:

13 See Brooks (1995, p. 192): "They imply that Milly has at last lived her life, and has plumbed the depths of her mortal abyss, in order that she be understood, that her sign be legible and that it signify in the lives of others, including the 'villain'. In Kate's interpretation, we are made to feel that Milly has chosen the terms of her life and death in order for her sign to dominate the stage, to be read and recognized". 
"She's a dove", Kate went on, "and one somehow doesn't think of doves bejewelled. Yet they suit her down to the ground".

"Yes - down to the ground is the word." Densher saw now how they suited her, but was perhaps still more aware of something intense in his companion's feelings about them. Milly was indeed a dove; this was the figure, though it most applied to her spirit. Yet he knew in a moment that Kate was just now, for reasons hidden from him, exceptionally under the impression of that element of wealth in her which was a power, which was a great power, and which was dove-like only so far as one remembered that doves have wings and wondrous flights, have them as well as tender tints and soft sounds. It even came dimly that such wings could in a given case - had, truly, in the case with which he was concerned - spread themselves for protection. Hadn't they, for that matter, lately taken an inordinate reach, and weren't Kate and Mrs. Lowder, weren't Susan Shepherd and he, wasn't he in particular, nestling under them to a great increase of immediate ease? All this was a brighter blur in the general light, out of which he heard Kate presently going on.

"Pearls have such a magic that they suit everyone."

"They would uncommonly suit you", he frankly returned.

"Oh yes, I see myself!"

As she saw herself, suddenly he saw her - she would have been splendid; and with it he felt more what she was thinking of. Milly's royal ornament had under pressure now not wholly occult - taken on the character of a symbol of differences, differences of which the vision was actually in Kate's face. It might have been in her face too that, well as she certainly would look in pearls, pearls were exactly what Merton Densher would never be able to give her. Wasn't that the great difference that Milly to-night symbolised? She unconsciously represented to Kate, and Kate took it in at every pore, that there was nobody with whom she had less in common than a remarkably handsome girl married to a man unable to make her on any such lines as that the least little present. (pp. 565-566) ${ }^{14}$

Doves are also the symbol of the Holy Ghost, and it is no wonder that Milly's ostentation and vulgar display of her immense wealth keep her "to the ground". They suit her, in Kate's opinion, insofar as she bears the innocence of the simple-minded and the poor-spirited; they do not suit her, however, insofar as she is the stupid little creature too doomed by her idiocy to make good use of the blisses of what she has. If pearls are magic, it is because they suit everyone, even Milly. As Kate sees Milly, she sees herself, herself the bearer of the pearls, the receiver of the gift that

14 For a different reading of this scene, see Holland (1964, pp. 308-310). 
Milly's failing body will make as it is about to perish. And Densher sees, in this mirror-like scene, that Kate has completely dissociated herself from herself, from the poverty-stricken, awfully intelligent, terribly ambitious woman pressured by her impecunious family to get rich. Kate is blind to Milly's manipulation of her own image, unable to see that she has also been playing a part. Milly has taken, one after another, the attributes of stupidity imposed on her. It is Densher who shows skepticism: he is the one who realizes that the dove's riches are not just a sign of her vulgar groundedness, keeping her spirit from ascension; they are also a reminder of her power, of the financial protection her wealthy wings can bring, under which one finds solace from the miseries of this world. If Kate, in her infernal, excessive cleverness, dupes herself and treats Milly as a target, Densher understands her as a sovereign (her pearls, the symbol of her grounding wealth, are a "royal ornament") who is well aware of the power she exerts and holds. In the final scene of the novel, however, Kate finally sees it: "I used to call her, in my stupidity - for want of anything better - a dove. Well, she stretched her wings, and it was to that they reached. They cover us" (p. 689). For want of anything better, Milly's failing body covered in pearls is a harbinger of what is to come: her death, which becomes a gift as it gives Densher and Kate the means to marry. What is, Kate reasons, the use of a dove covered in heavy, opulent, royal ornaments? She fails to see that it is the serpent that is down on the ground, enticing her, with the suggestion of the forbidden fruit (her pearls), to reach for that which she cannot have. ${ }^{15}$

15 See Bersani (1984, p. 142): "In part, we have in 'The Wings of the Dove' a social drama involving distinctly different individuals. But their distinctness is threatened by the resemblances among the various narrative blocks: all the principal centers - first Kate, then Milly and finally Densher - seem to be reenacting the moral choice of the mind from whose point of view the story is really being enacted. It's as if we had three images of the self confronted with the alternatives of the world of the lioness and the world of the dove. And when Kate has chosen the former and Milly the latter, they allegorically become their choice for the final and most crucial spiritual performance, which is of course Densher's". For me to agree with Bersoni's words, however, Densher's "spiritual performance" has to be strictly seen as a performance, as an act, for, as I have mentioned, I see his refusal of Milly's gift as a selfish disavowal of responsibility. This performance, we can deduce, has three spectators: Kate, the reader, and Densher's own consciousness. However, a page later, Bersani (1984, p. 143) expresses his dislike of Densher: "James, whose center-of-consciousness method leaves an ample margin for ironic comment, is strikingly tolerant of Densher's self-righteous conclusion that he's behaving decently toward Milly simply by remaining perfectly still and refusing to lie with his lips (a strategy which serves Kate's plan beautifully)". 
Moreover, Milly's frail body covered in opulence is a site of stupidity. In Stupidity, Ronell (2002, p. 186) reminds us that

there is yet another dimension of the stupid to which infirmity subjects us, one that remains indifferent to those registers of stupidity still affected by the fading empire of cognition. Without knowing, the body is not, as such, ignorant either. A literality that is no longer legible, this body at once withholds itself and produces resistant signs of itself.

Milly's failing body, like her American constitution, needs to be read and made sense of, undergoing, in this diagnosis, "an excess of discourse" (RONELL, 2002, p. 186). On numerous occasions Kate functions as the reader of Milly's health, claiming that, despite appearances, she is not well. Kate's surplus reading sees Milly's body as the locus of enrichment, a body that has been stupidly reified and made to mean wealth, that is, the synecdoche for which Milly's pearls stand in the scene discussed above. If Milly's pearls ground her, if they stop the flight of the dove, they also symbolize Milly's spread-out wings that provide for the community. "Illness at once grounds the body here on earth, marking its subjection to time and destruction in time, but it also suspends, while reestablishing, the very corporeal contingency under whose rule it operates" (RONELL, 2002, p. 186). While Kate sees it as a bestowal, Milly's death is the implementation of her life, of her learning to live as the victim, of her education by means of victimization. ${ }^{16}$ Kate stupidly reads Milly's stupid body, unsuspecting that Milly's victimization does not depend only upon her, Kate's, hands, but also on Milly's sense of life and death, the meanings she must attribute to her own life in order to "achieve, however briefly and brokenly, the sense of having lived". ${ }^{17}$

16 Naqvi (2007, p. 11) reminds us that victimhood can be primarily understood within a religious logic, and that the double meaning of the German word Opfer (both "victim" and "sacrifice") is central in Freud's understanding of victimization: "When we interpret Freud's society of victims and victimizers in Totem and Taboo as a psychical construction accounting for the dynamics of human fellowship, sacrificial victimage - the condition of being a victim as well as the practice of seeking out a symbolic victim for purposes of expiation (OED Additions 297) - becomes the necessary precondition for society's development".

17 See Bersani (1984, pp. 145-146) apropos of Densher's equivocal reading of Milly for a counterpart of my reading of Kate's: "The community of consciousness achieved in "The Wings of the Dove" is an impressive warning of the very dangers to community in the critically minded Densher's 'reading' of the 'text' of Milly. He literally makes her his own, destroying the real peculiarity of her presence which we feel early in the work. Densher illustrates how a language of appreciation runs the risk of generalizing the particular too 
In the mock-religious text as which "The Wings of the Dove" can be read, Milly's performance is also the performance of her death. But as I have been arguing, the sense attributed by her to her death (and therefore to her life) depends on a legitimizing victimhood she achieves through her performance of the attributes imputed to her, all of them clustered under the wings of stupidity. If "performance" can be broadly understood as "all the activity of an individual which occurs during a period marked by his continuous presence before a particular set of observers and which has some influence on the observers" (GOFFMAN, 2003, p. 61), ${ }^{18}$ this incorporation of Milly by her circle of friends is related to her own incorporation of the ideologies attributed to her. ${ }^{19}$ Ideology, we know from the work of Slavoj Žižek, is more on the side of cynicism than that of belief, and her performance of the ideologies bestowed upon her is to meet the expectations of her observers: she has been offered the gift of stupidity, the stupidity about America stupidly concocted by European minds, and she will perform it. As Laurence Holland (1964, p. 295) suggests,

Milly is imagined as an explorer and adventurer, at once naïve and empirical. Wanting in culture, odd looking and new, she is the "potential heiress of all the ages" that it took Europe centuries to produce - the American, that is, of history and legend whom Densher calls simply "the American girl" and whom

successfully, thereby eliminating the unassimilable differences among individuals without which community extends no further than the reaches of one man's ingenuities". I dare say that this tendency to misread Milly is characteristic of the community of which she is part: for Kate she is the princess and the dove; for Luke Strett, the doctor, she is a creature in need of love; for Lord Mark, she is the odd American specimen being duped by Kate and Densher, when he himself wishes he could dupe her (this is Densher's reading of his reading of Milly); last but not least, for Mrs. Stringham, she is the frail creature in need of protection, even if this protection means being abused and lied to.

18 I understand "play" throughout this essay from an ethical standpoint that produces ambiguity and encompasses reading in what Armstrong (2005) has called "the ethics of play". Armstrong sees play as "a way of mediating (but not transcending) cultural differences precisely because worlds can exclude each other and because no generally persuasive version of truth can be found that would be acceptable to all communities of belief. Exclusion as the irreducibility of difference is what makes play possible and necessary" (p. 37).

19 A comment on Eugenia, a character from The Bostonions, by Bersani (1984, p. 137) seems to apply to Milly: she is created by the responses to her performance. In the context of this chapter, the following remark also proves relevant: "It's frivolous to see in James only a limitless faith in the civilizing powers of intelligence, or to think of his trust in consciousness as a naïvely hopeful dream of escape from the constraints of experience. Society and personality are more likely to be victimized by the autonomy of intelligence responsive only to its own discriminatory logic" (BERSANI, 1984, pp. 141-142). 
the novel renders in terms of "spontaneity" and simplicity, with her way of doing always "the natural thing".

Her doing "the natural thing" is tantamount to her coming from the wilderness; she is simple and rich, she has no manners, she is an ambulatory case of indecorum. She is American capitalism vulgarly displayed in the ostentation of her riches, her good nature and good-heartedness, her freshness and simplicity of spirit. At the beginning of Book 3, when Milly is shown to us for the first time (that is, shown to us through Mrs. Stringham's consciousness), Mrs. Stringham mulls over "the style in which our young woman could affect those who were near her, [which] may testify to the sort of interest she could inspire" (p. 293). In fact, Milly "reduces" those who circle her to "a consenting bewilderment" (p. 293) which, as we have seen, is in itself a type of consenting stupidity. Their stupidity is that of their thinking her stupid: Mrs. Stringham reasons that, "for stupid people", Milly's greatness would "take a great deal of explaining", that is, explaining "her beauty", the fact that "she exceeded, she escaped measure" (p. 294). Confronted with the stupidity of others - "and who, she sometimes secretly asked herself, wasn't stupid?" - she plays along, "employing the word that most people employ", this "to pretend that she was also stupid and so have done with the matter" (p. 294). Let us keep in mind that Mrs. Stringham, sometime after their arrival in Europe, suspects that Milly is just yet another case of "American intensity", and that soon she will break down into a "complicated drama of nerves" (p. 293). But this explanation, she reasons some time later, is "coarse", and though she cannot precisely put down in words what the key to the reading of Milly is (the explanation was "a muffled and intangible form"), there is, in this feeling of intangibility, "the light in which Milly was to be read" (p. 293). The narrator itself reminds us that Milly will get to us almost only by means of her associates: "we shall really ourselves scarce otherwise come closer to her than by feeling their impression and sharing, if need be, their confusion" (p. 293). Milly-in-herself, the thing-in-itself, is unrepresentable as such, and what we get is Milly-for-us, Milly's plurality of phenomena, the phenomena that are perceived by her associates' consciousnesses. Milly is patchwork, the patchwork of consciousnesses that take it as a given that she is "awfully full of things", that see in her oddness perhaps some tinges of idiocy (Milly's "queerness" and "funny manners" are constantly mentioned in the text). Upon meeting Milly, Mrs. Stringham is overwhelmed by the "weight of 
responsibility" she has been given, the responsibility for "the void to be filled" concerning Milly's lack of culture: "the key of knowledge was felt to click in the lock from the moment it flashed upon Mrs. Stringham that her friend had been starved for culture" (p. 288). Key or no key, Mrs. Stringham reads Milly; but since Milly is never there as an entity, but as a multiplicity of translations, Milly's unrepresentability, as we have seen acknowledged by the narrator itself, must also be bound to ideologies that pre-represent her. Didn't James, in any event, tell us in the preface that Milly bears a "perfect rightness for her part", for there are "fifty reasons for her national and social status" (p. 200)? Robert Pippin (2000, p. 5) provides a satisfactory tentative explanation: "America", in James's imaginary, is "the name for such a collapse of the reliability of traditional form, such uncertainty and new vacancy as well as radical possibility." Milly, perhaps one of James's most complex American girls, therefore offers her associates, the reader, and James himself, now in a displacement of Pippin's words (who is addressing modernity's "lack of common authority for fixed, predictable social norms"), "very little to rely on, little way to predict, expect, assume, little basis even for a minimum trust, little clarity about what a 'person' is or can be expected to do" (PIPPIN, 200o, p. 6).

I have been reading Milly according to a set of postulates that link her Americanness to a performance of ideologies; if her Americanness is constantly usurped by stupidity, or, to put it differently, if she is judged stupid because of her Americanness, it follows that her Americanness offers itself as an element that may be manipulated, that it is an invitation, in its stupidity, to manipulation. But this is what others see, for I insist that she sees, quite melodramatically, that she must make good use of her "native wood-note". Her "native wood-note", therefore, is to play a central role in her final gesture - her gift. Her letter is burned: since its message remains unknown, one could argue that it never arrives at its destination. Its destination is postulated as a void, for we, as readers, are also barred from entering the chain of signifiers it contains. Furthermore, Milly, the addresser, has also ceased to be. What we have, then, is a dead letter. No addressee is there on the other side to sign the package, and there is no sender to whom it can return. In the final section of this article, I turn to how two scenes involving letters condense the problem of Densher's stupid passivity and comfortable disavowal of responsibility. 
“My Cleverness, I Assure You, Has Grown Infernal": ...- 326

\section{III}

Densher, Slavoj Žižek (2009, p. 135) suggests, can be read as “a model 'honest' bourgeois intellectual who masks his compromising attitude by 'ethical' doubts and restraints". In this final section, I do not imply that Densher is completely outside of what we could call an ethical consciousness, insofar as I believe that he is, indeed, affected by his role in Milly's demise. The crux of the question, however, is responsibility. Informing Kate, upon his return from Venice, that Lord Mark has told Milly that they, Densher and Kate, are secretly engaged, Densher (famously) adds that Milly "has turned her face to the wall" (p. 632). He proceeds: "She learned it, you see, too soon - since of course one's idea had been that she might never even learn it at all. And she had felt sure - through everything we had done - of there not being between us, so far at least as you were concerned, anything she need regard as a warning" (p. 632). Kate, the "true ethical hero" (ŽIŽEK, 2009, p. 132) of the novel, knows her share: "It wasn't through anything you did - whatever that may have been - that she gained her certainty. It was by the conviction she got from me" (p. 632). And an ironic Densher, besieged by feelings of guilt, exclaims: "Oh it's very handsome [...] for you to take your share" (p. 632). She does, indeed: "Do you suppose [...] that I think of denying it?" (p. 632). Kate proceeds to ask Densher to return to Venice, meet with Milly, and "tell her [Lord Mark is] mistaken” (p. 632). Densher, however, is unwilling to take his share: "Densher stared - he was stupefied; [... 'And to lie myself, you mean, to do it?' We are, my dear child, [...] I suppose, still engaged” (pp. 632-633).

"My dear child", this condescending and patriarchal qualification, abounds in the last book of the novel. This speech act of Densher's, recurrent as it is at the novel's end, initially seems to stem from an ethical standpoint that dictates that he, Densher, the man who thinks he has never "lie[d] with his lips" (p. 580), the pawn in Kate's infernal game to get rich, the passive man who takes it in, not lie to Milly's face. She has, after all, turned her face to the wall, so he reasons that lying to her face is an impossibility (he couldn't write, he claims, because "she had turned her face to the wall"). If he is unwilling to lie to her face, as well as prevented from doing so, since now we only have her back, it seems that, according to his logic, lying behind her back, never through words, but through a silent passivity, is acceptable. "Well, if you must know", he tells Kate, "and I want to be clear about it - I didn't even seriously think of a denial to her 
face" (p. 633, emphasis mine). When Milly's face is before his eyes, he believes he is not lying. Densher mistakes lying for voicing, lying through one's voice, perhaps assuming that, for it to be a lie, it must be uttered. In the following paragraphs, I will explore the relationship between the face, responsibility, and passivity in order to sketch a reading of what it means to be responsible, especially when the other of my responsibility has turned her face to the wall.

I suggested before that Milly's gift is a selfish one, therefore not truly an authentic gift (which would, Derrida claims, be free from indebtedness); it cannot be refused, for she has turned her face to the wall. A rushed interpretation would claim that it is Milly who turns her face away; therefore, if her face is not present as a sign of alterity, her "sacrifice" would efface Kate and Densher's responsibility for the violence done to her (this is the commonplace Christological reading of Milly's bequest). However, as we have learned from Levinas, coming across the face of the other, the true moment of an ethical responsibility toward the other, does not preclude a responsible engagement (nor an engagement with responsibility) should the other turn her face away. "I am responsible for the Other without waiting for reciprocity. [...] Reciprocity is his affair. [...] Because I am responsible for a total responsibility, which answers for all the others and for all in the others, even for their responsibility. The I always has one responsibility more than all the others" (LEVINAS, 1985, p. 98). In this sense, even if Milly's actions were in themselves sacrificial, thus expiating Densher's guilt in the name of love, Densher's responsibility remains the same. "Responsibility is what is incumbent on me exclusively, and what, humanly, I cannot refuse", Levinas (1985, p. 98) proceeds. For him, if responsibility, which is the heart of ethics, comes to be face-toface (what he calls des rapports de face à face), my denial of responsibility cannot be justified by what the other does. In this context, lying in silence and lying with words to one's face are ontologically the same, for neither exempts me from responsibly engaging with the other.

In Being and Time, Heidegger (2010, pp. 269-277) thinks authentic guilt as one's being ready to be summoned; guilt is not, Heidegger argues, indebtedness; indebtedness itself can only be said to exist because of Dasein's authentic being-guilty. In this sense, it is not the case that I am guilty because I owe, but rather that I owe because I am guilty. Densher's avoidance of responsibility is grounded in two non causa pro causa fallacies:a) cum hoc, ergo propter hoc-I will not take her money, therefore 
I am not guilty; and b) post hoc, ergo propter hoc - since I never "lied with [my] lips", I am not responsible for the lies I have not told. And perhaps, since she has turned her face to the wall, and I no longer see her face, I am not responsible for her alterity, given that her alterity, materialized in her face, has been barred from me. In other words, following Heidegger's understanding of responsibility, my being-guilty before the other pre-exists any sense of indebtedness. Densher reasons that, by not taking the money, he will not be responsible for Milly's death; he is also keen on stating that, should he lie to Milly's face, he would have to break up with Kate "to make" his "denial a truth" (p. 635). We discover in any event that he was "face to face" with Milly, but, since she did not ask him if it is true that he and Kate are engaged, he did not broach the topic: "I couldn't have done anything else', said Merton Densher. 'So you see how right I was not to commit myself, and how little I could dream of it. If it ever again appears to you that I might have done so, remember what I say'” (p. 635). Commitment, for Densher, is verbal. And when Kate throws Milly's timed letter into the fire, "he started - but only half - as to undo her action: his arrest was as prompt as the latter had been decisive [that is, Kate's jerking "the thing into the flame"]. He only watched, with her, the paper burn; after which their eyes again met" (p. 677). Densher must only half start; his "arrest" must be "prompt", for, by trying to save the letter, he would risk reading it, and, by reading it, learning what Milly knew. If she knows, if she voices her knowledge of his silent lie, this means she will be summoning him to face his very own responsibility; Densher, by not wanting to read the letter, does not want to take the call.

In the final scene of the novel, Kate comes to see Densher. She has "broken the seal" of the letter addressed to him from New York, which he conveniently, "to test" her, failed to open upon forwarding it to her. She immediately says:

"You see I’ve not hesitated this time to break your seal."

She had laid on the table from the moment of her coming in the long envelope, substantially filled, which he had sent her enclosed in another of still ampler make. He had however not looked at it - his belief being that he wished never again to do so; besides which it had happened to rest with its addressed side up. So he "saw" nothing, and it was only into her eyes that her remark made him look, declining any approach to the object indicated. "It's not 'my' seal, my dear; and my intention - which my note tried to express - was all to treat it to you as not mine." 
"Do you mean that it's to that extent mine then?"

"Well, let us call it, if we like, theirs - that of the good people in New York, the authors of the communication. If the seal is broken well and good; but we might, you know", he presently added, "have sent it back to them intact and inviolate. Only accompanied", he smiled with his heart in his mouth, "by an absolutely kind letter".

\section{[...] "Is it what you're proposing we should do?"}

"Ah, it's too late to do it - well, ideally. Now, with that sign we know -"

"But you don't know", she said very gently.

"I refer [...] to what would have been the handsome way. Its being dispatched again, with no cognisance taken but one's assurance of the highest consideration, and the proof of this in the state of the envelope - that would have been really satisfying."

She thought for an instant. "The state of the envelope proving refusal, you mean, not to be based on the insufficiency of the sum?"

Densher smiled again for the play, however whimsical, of her humour. "Well yes - something of that sort."

"So that if congnisance has been taken - so far as I'm concerned - it spoils the beauty?"

"It makes the difference that I'm disappointed in the hope - which I confess I entertained - that you'd bring the thing back to me as you had received it. [...] Well, I wanted - in so good a case - to test you." (pp. 684-685)

If the first letter, that which was "addressed to [Densher] in her hand", becomes a dead letter (for no one will ever read it), the second, that which contains the check that has been sent by New York, finds a displaced addressee, thus arriving at a displaced destination. This displacement, I am arguing, is Densher's refusal of responsibility, which itself lies in his assumption that he never lied to Milly's face. In the passage above, Densher's language is one of disavowal: "it is not 'my' seal", "let us call it theirs", "have sent it back to them intact and inviolate", "what would have been the handsome way", "its being dispatched again", to name but a few instances. This language of disavowal, combined with his "newfound" aggressive, patronizing, and arguably misogynistic language, does not consist only in his not taking responsibility, but also in his imputing responsibility to Kate. He is testing her, testing her willingness to accept 
his disavowal. He wants Kate "to join with [him] in doing so" (p. 686), that is, refusing the money (which, as I have been proposing, means refusing responsibility for his actions). And I strongly hold that Kate's "How can I 'join' in a matter with which I've nothing to do?" (p. 686) should not be read as her disavowal, but rather as her claim that his responsibility is his own business, not hers. Kate believes that Milly "never wanted the truth", that she would "have thanked" and "blessed" Densher's lying "from pity" (p. 635); Kate can even be said to regard Densher's acceptance of the gift not only as a duty to her, Kate, but also to Milly: "She would have taken from you what you could give her and been glad of it, even if she had known it false". If Densher doesn't "touch the money", "who then in such an event will?" (p. 686).

Whether or not Milly's gift is an act of generosity, revenge, or more likely both, Densher's choice is the choice of not choosing. Perhaps like Bartleby, he would simply prefer not to. This reiterates his passivity, insofar as, if he is not responsible, he only passively participated in the game: he never lied, that is, formalized his responsibility, or so he thinks. He plays stupid throughout the novel, rambling about London and Venice in a state of bewilderment and stupor; but he manages to bend Kate's own morality by blackmailing her into coming to his rooms, an action to which he later refers as her "sacrifice". In the blackmail scene Densher plays stupid, claiming that he does not get what Kate's plan is all about. She does not want to call a cat, growing impatient with his play of stupidity and passivity: "Don't think, however, I'll do all the work for you. If you want things named you must name them" (p. 635). To which he replies:

"Since she is to die I'm to marry her?"

$[\ldots]$

"To marry her."

"So that when her death has taken place I shall in the natural course have money?" It was before him now, and he had nothing more to ask; he had only to turn, on the spot, considerably cold with the thought that all along - to his stupidity, to his timidity - it had been, it had been only, what she meant. (p. 635)

As he realizes he has been passively stupid (or stupidly passive), he asks her: "All right? [...] You'll come?" (p. 570). Kate says that she is, after all, "a person, thank goodness, who can do what I don't like", a statement 
Densher reads with "a kind of ironic ring, a note of character that belittled his own incapacity for action" (p. 571). However, "he saw indeed even at that time the greatness of knowing so well what one wanted. At the time too, moreover, he next reflected that he after all knew what he did" (p. 571). His passive stupidity suddenly goes silent: "Well, [...] I'll stay [in Venice and court Milly], on my honor, if you'll come to me. On your honor" (p. 573). This is exactly when the formerly stupid, passive man refuses to play the game unless it is played on his terms (and on her honor, for he plays on her honor as much as he plays on Milly's love to get what he wants):

"If you decline to understand me I wholly decline to understand you. I'll do nothing."

"And if I do understand?"

"I'll do everything."<smiles>[CH]1[CH]C=C1</smiles>

"Well, I understand."

“On your honor?"

"On my honor."

"You'll come?"

“'ll come." (pp. 573-574)

Densher's post-orgasmic impressions follow, in fact, a phallic logic that belies his passivity:

Luckily he didn't wish [to "banish" from his rooms "what survived of" Kate], even though there might be for a man almost a shade of the awful in so unqualified a consequence of his act. It had simply worked, his idea, the idea he had made her accept; and all erect before him, really covering the ground as far as he could see, was the fact of the gained success that this represented. (p. 575)

He did not wish to banish what survived of her from his rooms, though something awful results from keeping it; the consequence of his act is his demoralization of Kate, rather the demoralization he blackmails her into accepting.

In any event, Densher's responsibility is also displaced from him to Kate in James's initial conception of the story. On November 3, 1894, James 
(1988, p. 104 $)^{20}$ writes an entry in his notebook that sketches what would eventually become "The Wings of the Dove". He had, however, to stop: "I was pressed for time and it was taking me too far" (p. 104). He returns to his notebook on November 7 , but, after three days of reflection, he radically alters his initial scenario. At first, our "young man" would come across the dying girl, take pity on her, "give her something that it breaks her heart to go without having known. That 'something' can only be - of course - the chance to love and to be loved" (p. 103). But "he is not in love with her", for he "is entangled with another woman, committed, pledged, 'engaged' to one - and it is in that that a little story seems to reside" (p. 103). However, as James tries to work out his plot, he realizes that, should the young man just have sex with the dying woman, an idea "which at first appeared essential to it", this would be ugly, incongruous, and nasty: "such a remedy only" for her "despair" would be "vulgar", "sufficiently second-rate" (p. 103). It is delightful to see how James himself struggles to make this "little idea” worth it: "Oh, she's dying without having had it? Give it to her and let her die" (p. 103). No, James reasons, this is what the French would appreciate, not an English audience, for "one can do so little with English adultery" (p. 103). No, James thinks, this would be too bland for the English. The way to spice things up is by turning Densher into a scheming gold-digger: "He takes his betrothed, his fiancée, fully into his confidence about her and says, 'Don't be jealous if I'm kind to her - you see why it is"'. The fiancée at first takes pity on the dying girl, though things "go further than she quite likes" (p. 104).

And at this moment when things are going too far, too "ugly and vulgar", James stops. These eruptions of ugliness and vulgarity that seem to punctuate his "little idea" would contradict his first conception of Milly: "I seem to get hold of the tail of a[nother] pretty idea in making that happiness, that life, that snatched experience the girl longs for, BE, in fact, some rapturous act of that sort [bequeathing him her fortune] some act of generosity, of passionate beneficence, of pure sacrifice, to the man she loves" (p. 105). However, it "dimly" comes to James that Densher's responsibility for the farce must be displaced to Kate: "I think I see the thing beginning with the 2 girls - who must not love each other. [...] One may see the story begin with them - the two together; brought a little nearer by the girl's illness and trouble - so that the other is the FIRST

20 All quotations that follow are from this edition. 
witness of her despair and had the FIRST knowledge of her doom" (p. 105). Kate then becomes the mastermind of the plot against Milly: "The fiancée has a plan. [...] Her plan is that he shall give himself to her for the time, be 'nice' to her, respond, express, devote himself to her, let her love him and behave as if he loved her" (p. 105). And the formerly cunning young man, now metamorphosed into a passive being, "rather mystifiedly and bewilderdly assents" (p. 105).

Densher is now confused, stupefied, he becomes the stupid man who passively assents. James inverts Densher's role so much that Kate's "sacrifice", identified in the novel, as we have seen, as her having slept with Densher, in the notebook would only entail her not marrying Lord $\mathrm{X}$ (Mark); her sacrifice is her not having his title, "nothing else" (p. 106). "Then the young man is left with the money face to face with his fiancée." When the other's face stares at me, I always have the option of turning my face away: he "consented in a manner to become the instrument" of his fiancée's "game" (p. 106). "All this revolts him and puts him off. In the light of how exquisite the dead girl was he sees how little exquisite is the living" (p. 106).

Responsibility, James seems to think, was too much for Densher to take. So it is Kate who will have to carry the burden. Finally understanding what the man she loves is like, and what he has done (and achieved) by playing stupid, she sees, finally acknowledging her stupidity, that, money or no money, their relationship is over - not because of Milly, or his alleged love for Milly, but because of his refusal to take his share of accountability. From that moment onwards, they shall never be again as they were.

\section{"MINHA ESPERTEZA, GARANTO, TORNOU-SE INFERNAL": FAZENDO-SE DE BESTA COM HENRY JAMES}

Henry James Resumo: Este artigo considera o preconceito de Henry James quanto à sua América natal de modo irônico. Propõe uma leitura da encenação da estupidez em duas partes: primeiramente como estratégia de resistência; em seguida, como recusa de responsabilidade. Sugere que Henry James fornece a Milly Theale, a protagonista americana de "The Wings of the Dove", a oportunidade de tirar proveito de concepções europeias do Novo Mundo através da encenação da estupidez. Entretanto, fazer-se de estúpido também significa recusar qualquer responsabilidade, como o caso de Merton Densher ilustra. James não resolve a questão, deixando à estupidez seu poder.

Palavras-chave: Henry James; ética; crítica ideológica. 
“My Cleverness, I Assure You, Has Grown Infernal”: ...- 334

\section{WORKS CITED}

ARMSTRONG, Paul B. Play and the Politics of Reading: The Social Uses of Modernist Form. Ithaca: Cornell University Press, 2005.

BERSANI, Leo. A Future for Astyanax: Character and Desire in Literature. New York: Columbia University Press, 1984.

BROOKS, Peter. The Melodramatic Imagination: Balzac, Henry James, Melodrama, and the Mode of Excess. New Haven: Yale University Press, 1995.

CAMERON, Sharon. Thinking in Henry James. Chicago: The University of Chicago Press, 1991.

DERRIDA, Jacques. Donner le temps: 1. La fausse monnaie. Paris: Galilée, 1991.

DERRIDA, Jacques. Spectres de Marx: l'état de la dette, le travail du deuil et la nouvelle Internationale. Paris: Galilée, 1993.

DERRIDA, Jacques. Donner la mort. Paris: Galilée, 1999.

DERRIDA, Jacques. Apprendre à vivre enfin: entretien avec Jean Birnbaum. Paris: Galilée, 2005 .

FOWLER, Virginia. Henry James's American Girl: The Embroidery on the Canvas. Madison: The University of Wisconsin Press, 1984.

GILJE, Paul A. The Rise of Capitalism in the Early Republic. In: GILJE, Paul A. (Ed.). Wages of Independence: Capitalism in the Early American Republic. Plymouth: Rowman \& Littlefield Publishers, 2006.

GOFFMAN, Erving. Performances. Belief in the part one is playing. In: BIAL, Henry; BRADY, Sarah (Eds.). The Performance Studies Reader. New York: Routledge, 2003.

HEIDEGGER, Martin. Being and Time. Trans. Joan Stambaugh. Albany: SUNY Press, 2010.

HOLLAND, Laurence. The Expense of Vision: Essays on the Craft of Henry James. Princeton: Princeton University Press, 1964.

JAMES, Henry. Hawthorne. In: Essays: American and English Writers. New York: The Library of America, 1984.

JAMES, Henry. The Notebooks of Henry James. Eds. Leon Edel and Lyall Harris Powers. Oxford: Oxford University Press, 1988.

JAMES, Henry. Americans Abroad. In: Collected Travel Writings. New York: The Library of America, 1993[1878]. 
JAMES, Henry. The Portrait of a Lady. Ed. Robert D. Bamberg. New York: W.W. Norton \& Company, 1995[1880-1881].

JAMES, Henry. A Light Man. In: Complete Stories 1864-1874. New York: The Library of America, 1999[1869].

JAMES, Henry. The Wings of the Dove. In: Novels 1901-1902. New York: The Library of America, 2006[1902].

LEVINAS, Emmanuel. Ethics and Infinity. Tans. Richard A. Cohen. Pittsburgh: Duquesne University Press, 1985.

McCALL, Dan. Henry James's Hawthorne. New England Review (1990-), v. 18, n. 4, 1997, pp. 111-118.

MENGUE, Philippe. Faire l'idiot: la politique de Deleuze. Paris: Germina, 2013.

MILLER, J. Hillis. Literature as Conduct: Speech Acts in Henry James. New York: Fordham University Press, 2005.

NAQVI, Fatimah. The Literary and Cultural Rhetoric of Victimhood. New York: Palgrave Macmillan, 2007.

PIPPIN, Robert. Henry James and Modern Moral Life. Cambridge / New York: Cambridge University Press, 2000.

PUCKETT, Kent. Bad Form: Social Mistakes in the 19th-century Novel. Oxford / New York: Oxford University Press, 2008.

ROBERTS, Priscilla. The Geopolitics of Literature: The Shifting International Theme in the Works of Henry James. The International History Review, v. 34, n. 1, March 2012, pp. 89-114.

RIGHTER, William. American Memory in Henry James: Void and Value. Aldershot: Ashgate, 2004.

RONELL, Avital. Stupidity. Urbana / Chicago: The University of Illinois Press, 2002.

YEAZELL, Ruth. Language and Knowledge in the Late Novels of Henry James. Chicago: Chicago University Press, 1976.

ŽIŽEK, Slavoj. The Parallax View. Cambridge: The MIT Press, 2009. 